\title{
First report of Borrelia burgdorferi sensu lato in two threatened carnivores: the Marbled polecat, Vormela peregusna and the European mink, Mustela lutreola (Mammalia: Mustelidae)
}

\author{
Călin M Gherman ${ }^{1}$, Attila D Sándor ${ }^{1,2^{*}}$, Zsuzsa Kalmár ${ }^{1}$, Mihai Marinov ${ }^{3}$ and Andrei D Mihalca ${ }^{1}$
}

\begin{abstract}
Background: Lyme disease is a widespread cosmopolitan zoonosis caused by species belonging to the genus Borrelia. It is transmitted from animal reservoir hosts to humans through hard - ticks of genus Ixodes which are vectors of the disease.
\end{abstract}

Case presentation: Borrelia burgdorferi sensu lato infection was identified in a marbled polecat, Vormela peregusna, and two European minks, Mustela lutreola, from Romania, by PCR. RFLP revealed the presence of a single genospecies, Borrelia burgdorferi sensu stricto.

Conclusions: This is the first report of the Lyme disease spirochetes in the two mentioned hosts.

Keywords: Borrelia burgdorferi s.s, First report, Mustela lutreola, Vormela peregusna, Romania

\section{Background}

Borrelia burgdorferi sensu lato is the causative agent of Lyme borreliosis, the most widespread vector-borne disease in the cool-temperate regions of the Northern hemisphere. The medical importance of this pathogen is generally restricted to humans and few domestic species. However, as for many vector-borne diseases, the key to the understanding of the epidemiology of Lyme borreliosis consists in revealing the ecological relationships that exist between pathogens, vectors and wildlife hosts [1]. All 18 currently recognized genotypes [2] circulate in nature between vectors (several ticks of genus Ixodes) and reservoir hosts (various vertebrates) which are able to maintain and transmit the spirochetes [3].

\footnotetext{
* Correspondence: adsandor@gmail.com

'Department of Parasitology and Parasitic Diseases, University of Agricultural Sciences and Veterinary Medicine, Faculty of Veterinary Medicine, Calea Mănăștur 3-5, Cluj-Napoca 400372, Romania

${ }^{2}$ Department of Taxonomy and Ecology, Babeş-Bolyai University, Faculty of Biology, Strada Clinicilor 5-7, Cluj-Napoca 400006, Romania

Full list of author information is available at the end of the article
}

\section{Case presentation}

Between 2009 and 2011, 5 specimens belonging to two species of threatened mustelids were brought to the Laboratory of Parasitology and Parasitic Diseases in deep frozen state (Table 1). The dead animals were collected either as road kills (Vormela peregusna) or as accidental casualties of live-trapping during field studies (Mustela lutreola). The trapping was performed as part of biodiversity and ecology studies in the central part of the Danube Delta using box traps [4]. The accidental death of animals in live traps was caused by extreme morning frost or poor overall health status caused by floods (Kiss JB personal communication). Examination of the fur and skin did not reveal the presence of external parasites.

During the necropsy of these animals, tissue samples (myocardium) were collected and processed for DNA extraction (Qiagen, DNeasy Blood \& Tissue Kit). An extraction blank was included in each extraction procedures to control the cross-contamination between extracts. The crude DNA was analyzed by a PCR protocol according to Priem et al. (1997) [5] using primers (Generi Biotech) for Borrelia burgdoferi sensu lato (5'-GGGAATAGGTCTAATTTAGCC-3', 5'-CACTAA 
Table 1 The collection localities of threatened Mustelidae specimens used in this study

\begin{tabular}{lllll}
\hline Sample & Species & Locality (County ${ }^{*}$ ) & Coordinates & Date \\
\hline ML1 & European mink (Mustela lutreola) & Canal Litcov (TL) & $45^{\circ} 08^{\prime} \mathrm{N} 29^{\circ} 19^{\prime} \mathrm{E}$ & 05.03 .2010 \\
ML2 & European mink (Mustela lutreola) & Canal Litcov (TL) & $45^{\circ} 08^{\prime} \mathrm{N}_{2} 9^{\circ} 18^{\prime} \mathrm{E}$ & 06.03 .2010 \\
ML3 & European mink (Mustela lutreola) & Canal Litcov (TL) & $45^{\circ} 08^{\prime} \mathrm{N} 29^{\circ} 18^{\prime} \mathrm{E}$ & 06.03 .2010 \\
VP1 & Marbled polecat (Vormela peregusna) & Sinoe (CT) & $44^{\circ} 37^{\prime} \mathrm{N} 28^{\circ} 43^{\prime} \mathrm{E}$ & 30.11 .2009 \\
VP2 & Marbled polecat (Vormela peregusna) & Agighiol (TL) & $45^{\circ} 02^{\prime} \mathrm{N} 28^{\circ} 53^{\prime} \mathrm{E}$ & 10.06 .2011 \\
\hline${ }^{*} \mathrm{CT}:$ Constanta; $\mathrm{TL}:$ Tulcea. & & &
\end{tabular}

TTGTTAAAGTGGAAGT-3') targeting the OspA gene [6]. Each time the PCR was performed including negative control samples. The positive PCR products were further analyzed by RFLP using two restriction enzymes $A l w l$ (BsPI) and MseI (Tru1 I) (Fermentas), according to the manufacturers protocol. PCR analysis revealed positivity to Borrelia burgdorferi sensu lato in three samples (ML2, ML3 and VP1) belonging to the two host species: $M$. lutreola and $V$. peregusna.

Analysis of the RFLP pattern of the amplified OspA gene cut, showed bands at 183/134/74 base pairs (bp) for MseI (Tru1 I) (Figure 1A) restriction enzyme and a second pattern at 227/164 bp for Alwl (BsPI), which is indicative of Borrelia burgdorferi sensu stricto (s.s.) in all three positive samples (Figure 1B).

\section{Discussion}

Borrelia burgdorferi is maintained in natural cycles of infection by vector ticks and reservoir hosts. In Western and Central Europe, Ixodes ricinus is particularly important in the transmission of the Lyme spirochete. Moreover, $I$. hexagonus has been experimentally confirmed as a vector [7], but was also shown to be important in secondary cycles of $B$. burgdorferi transmission $[1,8]$. Both of them, together with other congeneric ticks, are well represented in mustelids (Table 2). Although ticks are commonly found on mustelids, $B$.

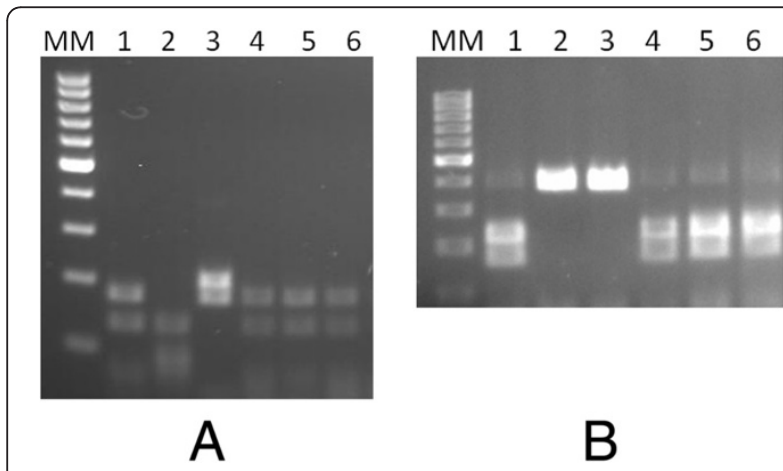

Figure 1 RFLP pattern of the amplified ospA gene cut with Msel (Trull) (A) and Alwl (BsPI) (B): M - 100 bp Molecular ladder (Fermentas). 1-3 - positive controls: B. burgdorferi s.S., B. garinii, B. afzelii, 4 - B. burgdorferi s.s. (Vormela peregusna), 5 - B. burgdorferi s.s. (Mustela lutreola), 6 - B. burgdorferi s.s. (Mustela lutreola). burgdorferi s.l. infection is rarely reported. The scarcity of reports can be explained either by the fact that the infection is rare or, most probably by the lack of studies on this topic.

Several authors have previously reported the presence of Borrelia burgdorferi s.l. in Ixodes ticks removed from mustelids: European badger (Meles meles) [9], American mink (Mustela vison) [10], weasel (Mustela nivalis) [11], beach marten (Martes foina), European polecat (Mustela putorius), and stoat (Mustela ermina) [12]. In Italy, none of the $I$. hexagonus and $I$. ricinus collected from beech marten was positive by PCR for B. burgdorferi s.l. [13].

An interesting study from Switzerland, where questing ticks were analyzed for the host of the previous feeding stage by Reverse Line Blotting revealed the presence of Borrelia burgdorferi s.l. DNA in specimens positive for Meles meles and Mustela putorius probes. The authors suggest the role of mustelids as reservoir hosts for Borrelia burgdorferi [14].

Other authors examined mustelids for the presence of anti-Borrelia burgdorferi s.l. antibodies. One least weasel caught in forests of the western part of France was seropositive for B. burgdorferi at $1 / 50$ antibody titer [15], however stoats from Canada infested with I. Scapularis (the most important vector of Lyme disease in North America) were seronegative [16].

To our knowledge, there is a single study showing the presence of B. burgdorferi s.l. DNA in tissues of mustelids. McDonald and Lariviere (2001) [17] found the infection in 10 of 45 stoats from Great Britain. However, no information was provided on the tissues examined or the genospecies identified. Here we report the first identification of B. burgdorferi s.l. from the myocardium of a marbled polecat and two European minks. The Marbled polecat, Vormela peregusna is widespread from Southeastern Europe to Russia, China and northern Africa [18]. It is listed by IUCN as vulnerable. The European mink, Mustela lutreola is a semi-aquatic species of mustelid native to Europe and it is listed by IUCN as Critically Endangered. Its current distribution includes small isolated populations in northern Spain, western France and Eastern Europe (Latvia, Estonia, Belarus, Ukraine, central regions of European Russia, the Danube Delta in Romania and northwestern Bulgaria) [19]. In Romania, 
Table 2 Check-list of Ixodid tick species associated with mustelids

\begin{tabular}{|c|c|}
\hline Ticks species & Mustelid hosts \\
\hline 1. acuminatus & $\begin{array}{l}\text { Mustela nivalis [22], Mustela putorius [22], } \\
\text { Mustela vison [23] }\end{array}$ \\
\hline 1. angustus & Mustela erminea [24] \\
\hline 1. cookei & $\begin{array}{l}\text { Mustela frenata [25], Mustela nivalis [26], } \\
\text { Mustela vison [26,27] }\end{array}$ \\
\hline \multirow[t]{2}{*}{ 1. crenulatus } & $\begin{array}{l}\text { Martes foina [28], Meles meles [24], } \\
\text { Mustela erminea [29], }\end{array}$ \\
\hline & $\begin{array}{l}\text { Mustela lutreola [30], Mustela nivalis [28], } \\
\text { Mustela putorius [31], Mustela vison [23], }\end{array}$ \\
\hline I. gregsoni & $\begin{array}{l}\text { Martes americana [32], Martes pennanti [33], } \\
\text { Mustela sp. [32], Mustela vison [32,33] }\end{array}$ \\
\hline \multirow[t]{3}{*}{ I. hexagonus } & Martes foina $[13,31,34-36]$, Mustela putorius $[31,35,36]$ \\
\hline & Mustela erminea [29,31,35-37], Mustela nivalis [31,38], \\
\hline & $\begin{array}{l}\text { M. putorius furo [31,39], Meles meles [34-36], } \\
\text { Mustela vison [23] }\end{array}$ \\
\hline 1. muris & Mustela vison [40] \\
\hline I. nipponensis & Mustela sibirica [41] \\
\hline 1. pacificus & Mustela frenata [42], Taxidea taxus [42] \\
\hline I. persulcatus & $\begin{array}{l}\text { Martes flavigula [37], Martes martes [37], } \\
\text { Meles meles [37], Mustela erminea [37], } \\
\text { Mustela nivalis [37], Mustela putorius [37], } \\
\text { Mustela sibirica [37] }\end{array}$ \\
\hline \multirow[t]{2}{*}{ I. ricinus } & $\begin{array}{l}\text { Martes foina }[13,22,35,37], \text { Martes martes [37], } \\
\text { Meles meles [14,35,37], Mustela erminea [14,29], } \\
\text { Mustela lutreola [37], }\end{array}$ \\
\hline & $\begin{array}{l}\text { Mustela nivalis [37], Mustela putorius [14,37], } \\
\text { Mustela vison [23] }\end{array}$ \\
\hline 1. rugicollis & Martes sp. [43] \\
\hline I. scapularis & Mustela erminea [16], Mustela frenata [25] \\
\hline I. tanuki & Martes flavigula [44] \\
\hline 1. texanus & Mustela frenata [25] \\
\hline I. ventalloi & Mustela nivalis [38] \\
\hline
\end{tabular}

both species are present in the Southeastern part of the country, Dobrogea $[20,21]$.

\section{Conclusions}

Detection of Lyme spirochete is relatively rare in mustelids, suggesting the limited role of these hosts in natural foci. The detection of pathogens in tissues or in ticks feeding on various vertebrates does not confer to these hosts the status of reservoir host, but rather carrier hosts. Hence, although it has been suggested that mustelids are reservoir hosts for B. burgdorferi s.l., experimental transmission is required to clarify this aspect.

\section{Competing interests}

All authors have seen and approved the manuscript and declare that they have no competing interest.

\section{Authors' contributions}

CMG conceived the study and drafted the manuscript. ADS made major contribution to the study design, identified the mustelid species and contributed to the writing of the manuscript. JK performed PCR and RFLP. MM had trapped the mustelids. ADM contributed to the writing of the manuscript. All authors read and approved the final manuscript.

\section{Financial support}

This study was funded from grant IDEI-PCCE CNCSIS 84, 7/2010, while ADS was supported by a research grant POSDRU/88/1.5/S/60185.

\section{Acknowledgements}

Special thanks to the three anonymous referees, who commented on an earlier version of the manuscript.

\section{Author details}

${ }^{1}$ Department of Parasitology and Parasitic Diseases, University of Agricultural Sciences and Veterinary Medicine, Faculty of Veterinary Medicine, Calea Mănăștur 3-5, Cluj-Napoca 400372, Romania. ${ }^{2}$ Department of Taxonomy and Ecology, Babeş-Bolyai University, Faculty of Biology, Strada Clinicilor 5-7, Cluj-Napoca 400006, Romania. ${ }^{3}$ Danube Delta National Institute for Research and Development, Strada Babadag 165, Tulcea 820112, Romania.

Received: 17 April 2012 Accepted: 13 August 2012 Published: 18 August 2012

\section{References}

1. Gern L, Humair P: Ecology of Borrelia burgdorferi sensu lato in Europe. In Lyme Borreliosis: Biology, Epidemiology and Control. Edited by Gray JS KO, Lane RS, Stanek G. New York: CABI Publishing; 2002:149-174.

2. Stanek G, Reiter M: The expanding Lyme Borrelia complex-clinical significance of genomic species? Clin Microbiol Infect 2011, 17(4):487-493.

3. Kahl O, Gern L, Eisen L, Lane RS: Ecological research on Borrelia burgdorferi sensu lato: terminology and some methodological pitfalls. In Lyme Borreliosis: Biology, Epidemiology and Control. Edited by Gray JS KO, Lane RS, Stanek G. New York: CABI Publishing; 2002:29-46.

4. Kranz A, Toman A, Marinov M Jr, Kiss JB: European mink research: results of the spring 2004 expedition. Sci Ann Danube Delta Inst Res Develop 2005, 11:42-44.

5. Priem S, Rittig MG, Kamradt T, Burmester GR, Krause A: An optimized PCR leads to rapid and highly sensitive detection of Borrelia burgdorferi in patients with Lyme Borreliosis. J Clin Microbiol 1997, 35(3):685-690.

6. Floris R, Menardi G, Bressan R, Trevisan G, Ortenzio S, Rorai E, Cinco M: Evaluation of a genotyping method based on the ospA gene to detect Borrelia burgdorferi sensu lato in multiple samples of Lyme borreliosis patients. New Microbiol 2007, 30:399-410.

7. Gern L, Toutoungi LN, Hu CM, Aeschlimann A: Ixodes (Pholeoixodes) hexagonus, an efficient vector of Borrelia burgdorferi in the laboratory. Med Vet Entomol 1991, 5:431-435.

8. Gern L, Rouvinez E, Toutoungi LN, Godfroid E: Transmission cycles of Borrelia burgdorferi sensu lato involving Ixodes ricinus and/or I. hexagonus ticks and the European hedgehog, Erinaceus europaeus, in suburban and urban areas in Switzerland. Folia Parasitol 1997, 44:309-314.

9. Gern L, Sell K: Isolation of Borrelia burgdorferi sensu lato from the skin of the European badger (Meles meles) in Switzerland. Vector Borne Zoonotic Dis 2009, 9(2):207-208.

10. Magnarelli LA, Swihart RK: Spotted fever group Rickettsiae or Borrelia burgdorferi in Ixodes cookei (Ixodidae) in Connecticut. J Clin Microbiol 1991, 29(7):1520-1522.

11. Gassner F, Verbaarschot P, Smallegange RC, Spitzen J, Van Wieren SE, Takken W: Variations in Ixodes ricinus density and Borrelia infections associated with cattle introduced into a woodland in The Netherlands. Appl Environ Microbiol 2008, 74(23):7138.

12. Piesman J, Gern L: Lyme borreliosis in Europe and North America. Parasitol 2004, 129(Suppl1):S191-S220.

13. Lorusso V, Lia RP, Dantas-Torres F, Mallia E, Ravagnan S, Capelli G, Otranto D: Ixodid ticks of road-killed wildlife species in southern Italy: new tick-host associations and locality records. Exp Appl Acarol 2011, 55:293-300.

14. Morán Cadenas F, RAIS O, Humair PF, Douet V, Moret J, Gern L: Identification of host bloodmeal source and Borrelia burgdorferi Sensu Lato in field-collected Ixodes ricinus ticks in Chaumon (Switzerland). J Med Entomol 2007, 44(6):1109-1117.

15. Doby JM, Betremieux C, Lambert MC, Lorvelec O, Rolland C, Costil C: Les micromammiferes forestiers reservoirs de germes pour Borrelia 
burgdorferi agent de la borreliose de Lyme ? Etude serologique de 296 animaux dans l'ouest de la France. Rev Med Vet 1991, 142(10):737-742.

16. Bouchard C, Beauchamp G, Nguon S, Trudel L, Milord F, Lindsay LR, Bélanger D, Ogden NH: Associations between Ixodes scapularis ticks and small mammal hosts in a newly endemic zone in southeastern Canada: Implications for Borrelia burgdorferi transmission. Ticks Tick Borne Dis 2011, 2:183-190.

17. McDonald RA, Lariviere S: Diseases and pathogens of Mustela spp., with special reference to the biological control of introduced stoat Mustela erminea populations in New Zealand. J Royal Soc New Zealand 2001, 31(4):721-744

18. Schreiber A, Wirth R, Riffel M, Van Rompaey H: Weasels, Civets, Mongooses and their relatives: an action plan for the conservation of mustelids and viverrids. Broadview: Kelvyn Press Inc; 1989

19. Maran T, Skumatov D, Palazón S, Gomez A, Põdra M, Saveljev A, Kranz A, Libois R, Aulagnier S: Mustela lutreola. In IUCN 2011. IUCN Red List of Threatened Species. Version 2011.2. <www.iucnredlist.org> Downloaded on 04 April 2012; 2012.

20. Călinescu R: [Mammals of Romania. Distribution and biogeographicaleconomic problems]. Buletinul Ministerului Agriculturii Domeniilor 1931 251:19-81 [in Romanian].

21. Cuzic M, Murariu D: [Data on the presence of the Marbled Polecat (Vormela peregusna Güld. 1770) in south-east Romania]. Studii Cercetări Stiinţele Naturii Muzeologie 2006, 3:193-198.

22. Santos-Silva MM, Beati L, Santos AS, De Sousa R, Núncio MS, Melo P, Santos-Reis M, Fonseca C, Formosinho P, Vilela C, Bacellar F: The hard-tick fauna of mainland Portugal (Acari: Ixodidae): an update on geographical distribution and known associations with hosts and pathogens. Exp Appl Acarol 2011, 55:85-121.

23. Page RJC, Langton SD: The occurrence of Ixodid ticks on wild mink Mustela vison in England and Wales. Med Vet Entomol 1996, 10:359-364.

24. Murrell BP, Durden LA, Cook JA: Host associations of the tick, Ixodes angustus (Acari: Ixodidae), on Alaskan Mammals. J Med Entomol 2003, 40(5):682-685

25. Carey AB, Krinsky WL, Main J: Ixodes dammini (Acari: Ixodidae) and associated did ticks in south-central Connecticut, USA. J Med Entomol 1980, 17:89-99.

26. Whitaker JO Jr, Goff R: Ectoparasites of wild carnivora of Indiana. J Med Entomol 1979, 15(5-6):425-430.

27. Kollars TM Jr, Oliver JH Jr: Host associations and seasonal occurrence of Haemaphysalis leporispalustris, Ixodes brunneus, I. cookei, I. dentatus, and I. texanus (Acari: Ixodidae) in southeastern Missouri. J Med Entomol 2003, 40(1):103-107

28. Caeiro V, Santos-Silva MM, Simōes AL, Núncio MS: Ixodes (Pholeoixodes) canisuga Johnston, 1949 uma espécie nova na ixodofauna em Portugal. Rev Port Cinc Vet 1997, 92:120-123.

29. Sleeman DP: Ectoparasites of the Irish stoat. Med Vet Entomol 1989, 3:213-218.

30. Corbet GB, Harris S: The Handbook of British Mammals. Oxford: Blackell Scientific Publications; 1991

31. Von Liebisch A, Walter G: Untersuchungen von Zecken bei Haus- und Wildtieren in Deutschland: Zum Vorkommen und zur Biologie der Igelzecke (Ixodes hexagonus) und der Fuchszecke (Ixodes canisuga). Dtsch Tierarzt/ Wschr 1986, 93:377-464.

32. Lindquist EE, Wu KW, Redner JH: A new species of the tick genus Ixodes (Acari: Ixodidae) parasitic on mustelids (Mammalia: Carnivora) in Canada. Can Entomol 1999, 131:151-170.

33. Lubelczyka CB, Hanson T, Lacombe EH, Holman MS, Keirans JE: First U.S. Record of the Hard Tick Ixodes (Pholeoixodes) gregsoni Lindquist, Wu, and Redner. J Parasitol 2007, 93(3):718-719.

34. Dias JATS, Núncio MS, Gongalves ACB: Contribuição para a elaboração de um inventário da fauna ixodoideológica (Acarina-lxodoidea) de Portugal. Garcia Orta Sér Zool 1994, 20:49-68.

35. Dominguez G: North Spain (Burgos) wild mammals ectoparasites. Parasite 2004, 11:267-272.

36. Toutoungi LN, Gern L, Aeschlimann A, Debrot S: A propos du genre Pholeoixodes, parasite des carnivores en Suisse. Acarologia 1991 32(4):311-328

37. Anderson JF, Magnarelli LA: Epizootiology of Lyme Disease-Causing Borreliae. Clin Dermatol 1993, 11:339-351.
38. Dias JATS, Santos-Reis M: A carraqa Ixodes ventalloi Gil Collado, 1936 como principal ectoparasita de uma populao de doninhas (Mustela nivalis Linnaeus, 1766) em Portugal. Garcia Orta Sér Zool 1989, 14:35-50.

39. Beichel E, Petney TN, Hassler D, Brückner M, Maiwald M: Tick infestation patterns and prevalence of Borrelia burgdorferi in ticks collected at a veterinary clinic in Germany. Vet Parasitol 1996, 65(1-2):147-155.

40. Walker ED, Stobierski MG, Poplar ML, Smith TW, Murphy AJ, Smith PC, Schmitt SM, Cooley TM, Kramer CM: Geographic distribution of ticks (Acari: Ixodidae) in Michigan, with special emphasis on Ixodes scapularis and Borrelia burgdorferi. J Med Entomol 1998, 35:872-882.

41. Kim HC, Han SH, Chong ST, Klein TA, Choi CY, Nam HY, Chae HY, Lee H, Ko S, Kang JG, Chae JS: Ticks collected from selected mammalian hosts surveyed in the Republic of Korea during 2008-2009. Korean J Parasitol 2011, 49(3):331-335.

42. Furman DE, Loomis EC: The ticks of California (Acari: Ixodida). Bull Calif Insect Surv 1984, 25:1-239.

43. Kolonin GV: World distribution of ixodid ticks (genus Ixodes). Nauka: Moscow; 1981 [In Russian].

44. Kitaoka S, Suzuki H: Studies on the parasite fauna of Thailand. 5. Parasitic ticks on mammals and description of Ixodes siamensis sp. $\mathrm{n}$. and Rhipicephalus tetracornus sp. n. (Acarina: Ixodidae). Trop Med 1983 25:205-219.

doi:10.1186/1746-6148-8-137

Cite this article as: Gherman et al.: First report of Borrelia burgdorferi sensu lato in two threatened carnivores: the Marbled polecat, Vormela peregusna and the European mink, Mustela lutreola (Mammalia: Mustelidae). BMC Veterinary Research 2012 8:137.

\section{Submit your next manuscript to BioMed Central and take full advantage of:}

- Convenient online submission

- Thorough peer review

- No space constraints or color figure charges

- Immediate publication on acceptance

- Inclusion in PubMed, CAS, Scopus and Google Scholar

- Research which is freely available for redistribution 